\title{
Phylogeography of the invasive polychaete Sabella spallanzanii (Sabellidae) based on the nucleotide sequence of internal transcribed spacer 2 (ITS2) of nuclear rDNA
}

\author{
F. P. Patti*, M. C. Gambi \\ Stazione Zoologica 'A. Dohrn', Laboratorio di Ecologia del Benthos, 80077 Ischia (Napoli), Italy
}

\begin{abstract}
Genetic relationships between different populations of the invasive species Sabella spallanzanii (Gmelin, 1791) (Polychaeta, Sabellidae) are investigated through the use of the internal transcribed spacer 2 (ITS2) of the nuclear ribosomal DNA (285 bp). Samples were taken from South Australian waters (3 populations), the Mediterranean Sea (8 populations) and the French Atlantic coast (1 population). The ITS2 sequences were analyzed using both maximum parsimony and unweighted pair-group mean analysis (UPGMA) algorithms; results showed genetic disjunction between the Australian and the Mediterranean populations. Within the Mediterranean populations, 3 different sub-groups, corresponding to different sub-basins, could be clearly detected (Northwestern, Central and Eastern basins). The Atlantic population showed strong differences with the Mediterranean and Australian populations, but did not allow the identification of the source of introduction from Europe to Australia. Data also suggest the occurrence of a reduced genetic variability of the Australian populations, probably due to the 'founder effect' of one introduction, either via ballast waters or hull fouling. The recent description of the life cycle and larval development of $S$. spallanzanii in the Mediterranean Sea, with a long pelagic larval phase and a post-settlement stage of metamorphosis (approx. $25 \mathrm{~d}$ ), supports the hypothesis of introduction via ballast waters (larval pool). Our data show high consistency when compared with the allozyme analysis previously performed by Andrew \& Ward (1997; Mar Ecol Prog Ser 152:131-143) on a reduced number of populations and emphasize the importance and suitability of ITS sequences as markers to study the genetic structure at the population level in $S$. spallanzanii.
\end{abstract}

KEY WORDS: Sabella spallanzanii · Polychaeta $\cdot$ Internal transcribed spacer $\cdot$ Biogeography $\cdot$ Minimum spanning network $\cdot$ Split decomposition $\cdot$ Ribosomal DNA $\cdot$ Biological invasions

\section{INTRODUCTION}

Biological invasions are a great drifting mine that can injure the integrity of natural communities of plants and animals and the preservation of endangered species. A 1993 report by the US Congressional Office of Technology Assessment (OTA) estimates that there are at least 4500 non-indigenous species (NIS) in

\footnotetext{
${ }^{*}$ Present address: Department of Organismic and Evolutionary Biology, Harvard University, 16 Divinity Ave, Cambridge, Massachusetts 02138, USA.

E-mail: fpatti@oeb.harvard.edu
}

the United States, representing 2 to $8 \%$ of all the taxonomic groups considered. Up to $15 \%$ of these NIS have significant ecological and/or economic impacts (OTA 1993, Ruiz et al. 1997). In the past $20 \mathrm{yr}$, isolated ecosystems, such as New Zealand and Australia, have been degraded by the invasion of NIS (Hallegraeff \& Bolch 1991, Hallegraeff et al. 1998). Although some marine invasions are the consequence of natural dispersal mechanisms, human-mediated invasions seem to be more common at present. In addition to obvious invaders, many NIS can be considered cryptogenic species due to the difficulty of demonstrating whether they are native or introduced (Carlton 1996). Numer- 


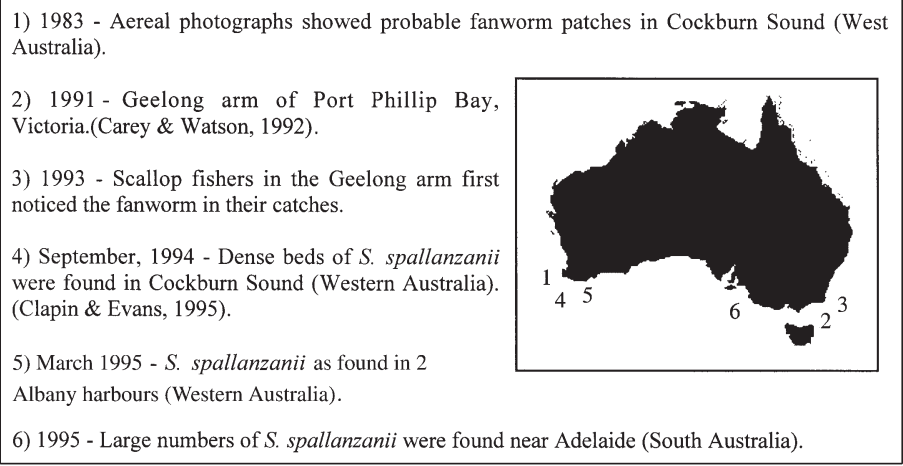

Fig. 1. Colonization patterns of Sabella spallanzanii around the Australian coast

ous aquatic invasions have occurred, and many of these now appear to be related to ballast water transport.

In the early 1990s a Mediterranean fanworm, Sabella spallanzanii (Gmelin, 1791) (Polychaeta, Sabellidae), was first documented to have been introduced into Australian waters (Fig. 1). S. spallanzanii now forms a kind of living carpet over parts of the floor of Port Phillip Bay, on the southeastern coast of Australia, to the detriment of the local scallop fishery (Carey \& Watson 1992, Clapin \& Evans 1995). S. spallanzanii, previously known as Spirographis spallanzanii (Knight-Jones \& Perkins 1998), is a tubicolous species and one of the most common polychaetes in many different coastal Mediterranean habitats, including very polluted ones (harbors, sewage outfall) (Giangrande \& Petraroli 1994, Giangrande \& Gambi 1998). It is also found on the eastern Atlantic coasts off Morocco (Bitar 1987), from Portugal to northwest France, and in the Azores (Andrew \& Ward 1997). This polychaete is relatively large-sized (up to $30-40 \mathrm{~cm}$ in length). Characteristic of the family are gills arising from 2 semicircular bases forming the crown, with the second lobe of the anterior extremity that is reversed constituting the collar. In adult specimens of S. spallanzani, one of the semicircular bases is small, while the other develops into an extremely long and spiraled crown.

To date, very little is known about the reproductive biology of Sabella spallanzanii. The first data, from a population off the Mediterranean (Giangrande \& Petraroli 1994), suggested that the species is a freespawner and a protandric hermaphrodite. More recent data from Australian waters (Currie et al. 2000) and the Mediterranean Sea (Giangrande et al. 2000) revealed that the species is gonocoric, with annual reproduction in winter (February in the boreal hemisphere, and August in the austral one), relatively slow oogenesis, and a rapid spermiogenesis. Mature sperm have a typ- ical ect-aquasperm structure (rounded nucleus and globose acrosome), are considered primitive, and are generally related to external fertilization (Jamieson \& Rouse 1989). Larval development, described only for the Mediterranean populations, revealed the presence of a lecithotrophic larva with a long pelagic phase (approx. $2 \mathrm{wk}$ ) before settlement and metamorphosis (Giangrande et al. 2000). This suggests the possibility of a high dispersal potential for this species.

To understand the relationship between genetic structure and geographic distribution in this invasive species, we examined 12 populations of Sabella spallanzanii, using an appropriate molecular marker (ITS2 region of the ribosomal DNA; Patti \& Gambi 1998) and comparing the results with allozyme results previously obtained by Andrew \& Ward (1997) on a smaller set of populations.

\section{MATERIALS AND METHODS}

Study sites and tissue materials. Twelve different populations were examined, 8 from the Mediterranean Basin, 1 from Roscoff, on the French Atlantic coast, and 3 deriving from the southern coasts of the Australian continent (Indian Ocean) (Victoria [Port Phillip Bay], South Australia [Adelaide harbor] and West Australia [Cockburn Sound]). Within the Mediterranean Sea populations were sampled from the Gulf of Naples (Ischia Island and Naples-S. Lucia), the 'Mar Piccolo' in Taranto (Ionian Sea), the Turkish coast (Çesme; oriental basin of the Mediterranean Sea), the French coast (Carteau, Banyuls and Marseille) and from the Spanish shore (near Alicante: Torrevieja) (Fig. 2). A related species of sabellid, Amphiglena mediterranea (Leydig 1851), was chosen as the outgroup. The individuals of the Australian populations, as well as those from Roscoff, Alicante, Carteau and Marseille, analyzed in the present paper, are the same as those used by Andrew \& Ward (1997) in their study on allozymes, and specimens were kindly provided by R. Ward. From each population 10 different individuals were screened.

DNA extraction and sequencing. After the extraction of the worms from their tubes, the tissues were fixed in absolute ethanol. Genomic DNA was extracted from the muscular tissue near the anterior end (collar and first thoracic segments); the coelomatic cavity was washed with ethanol to prevent DNA contamination by any ingested organic substance. Each tissue sample $(\sim 0.1 \mathrm{~g})$ was homogenized in a microcentrifuge tube in $600 \mu \mathrm{l}$ of $2 \times$ CTAB extraction buffer 

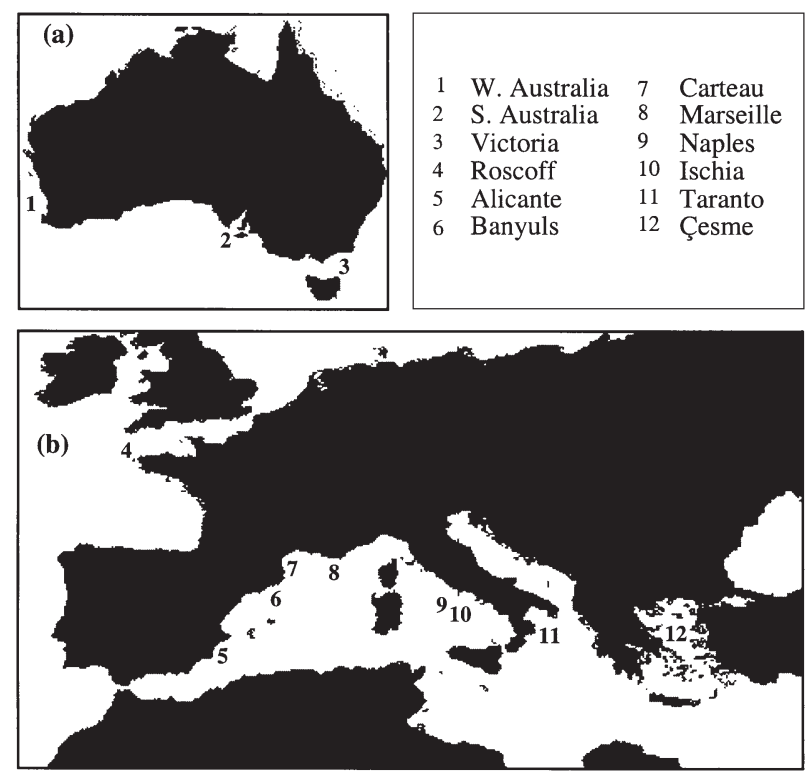

Fig.2 Sites of collection of Sabella spallanzanii populations in (a) Australia and (b) Europe

(50 mM Tris-HCl [pH 8.0], $0.7 \mathrm{M} \mathrm{NaCl}, 10 \mathrm{mM}$ EDTA, $1 \%$ CTAB (hexadecyltrimethylammoniumbromide), $0.4 \%$-mercaptoethanol; Doyle \& Doyle 1987) with proteinase $\mathrm{K}\left(100 \mathrm{mg} \mathrm{ml}^{-1}\right)$ and incubated at $60^{\circ} \mathrm{C}$ for 1 to $2 \mathrm{~h}$. In order to avoid the mucopolysaccharide production, which is induced by the presence of alcohol in the tissues, DMSO (dimethyl sulfoxide) was added to the extraction buffer. Each sample was then twice extracted with chloroform:isoamyl-alcohol (24:1), and nucleic acids were precipitated with 1 volume of ice-cold isopropanol. Nucleic acids were pelleted in a micro-centrifuge, dried under vacuum, and re-suspended in $200 \mu \mathrm{l}$ of $0.1 \times$ TE buffer $(10 \mathrm{mM}$ Tris and $1 \mathrm{mM}$ EDTA, $\mathrm{pH}$ 8.0). Five units of RNase (Boeringer-Mannheim) were added and the tubes were incubated at $37^{\circ} \mathrm{C}$ for $30 \mathrm{~min}$. Further purification of the DNA was performed with precipitation in absolute EtOH containing 1:10 of sodium acetate. The pellet was redissolved in $100 \mu \mathrm{l} 0.1 \times \mathrm{TE}$ and stored at $-20^{\circ} \mathrm{C}$

Polymerase chain reaction (PCR) amplification. The universal primer ITS-3 (5'-GCATCGATGAAGAACGCAGC-3) (White et al. 1990) and the specific primer D1-R (5'-AATCCCAARCAACYCGACTC-3) (Molecular Population Biology and Ecology Course, Friday Harbor Laboratories, 1998) were used to amplify and sequence the approximately 600 nucleotide fragment from the rDNA containing the 5.8S, the ITS2 and the first 2 domains of the 28S. Double-stranded amplifications were performed in a 9700 Perkin Elmer thermocycler with an initial denaturation step of $94^{\circ} \mathrm{C}$ for $1 \mathrm{~min}$ followed by 30 cycles of $95^{\circ} \mathrm{C}$ for $1 \mathrm{~min}, 50^{\circ} \mathrm{C}$ for
$1 \mathrm{~min}, 72^{\circ} \mathrm{C}$ for $1 \mathrm{~min}$, and a final step of $72^{\circ} \mathrm{C}$ for $5 \mathrm{~min}$. For each PCR reaction, $1 \mu \mathrm{l}$ aliquots of the DNA preparations $\left(\sim 10 \mathrm{ng}^{-1} \mathrm{l}^{-1}\right)$ were used as templates in $50 \mu \mathrm{l}$ PCR mix. The PCR reaction mix contained $0.15 \mu \mathrm{M}$ dinucleotide triphosphates (dNTPs), $2.5 \mathrm{mM} \mathrm{MgCl}_{2}$, $0.75 \mathrm{U}$ Taq DNA polymerase and $0.6 \mu \mathrm{M}$ of each primer. Amplifications were checked for correct length and purity after staining with ethidium bromide according to standard methods (Sambrook et al. 1989). Excess primers and nucleotides were removed from PCR products using GeneClean according to manufacturer's instructions. PCR products were sequenced directly with the Sanger method (Sambrook et al. 1989) using ${ }^{35}$ S-dATP and the T-7 polymerase kit from Pharmacia.

Sequence alignment and phylogenetic analyses. We limited the analysis to the spacer ITS2 ( 280 bp) because the other intergenic spacer (ITS1) showed multiple gaps, which do not allow correct alignment. All sequences obtained from the 10 individuals for each population were aligned using ClustalW ver. $1.6 \mathrm{~b}$ (Thompson et al. 1994, Thompson \& Gibson 1998) and alignment was manually refined using Genedoc ver. 2.3002 (Nicholas et al. 1997). All regions corresponding to a gap in a sequence were excluded from the analyses. Because different tree-building algorithms make different evolutionary assumptions and in order to compare our data with those acquired by an allozyme study, the aligned sequences were evaluated by maximum parsimony and Kimura's (1980) 2-parameter distance (unweighted pair-group mean cluster analysis [UPGMA]). Both methods were calculated within and between geographical groups. For the maximum parsimony method we used (1) the heuristic search, using branch-swapping with nearest-neighbor interchanges of PAUP* ver. 4.0b4a (Swofford 2000) and (2) the DNAPARS option (heuristic tree search) of Phylip ver. 3.5.6c (Felsenstein 1994). Bootstrapping was performed in both cases using the same settings. A 50\% majorityrule consensus tree was calculated from 1000 bootstrap replicates. The distances were calculated with the DNADIST option of Phylip ver. 3.5.6c. The distance matrix and the nucleotidic differences were generated using Mega ver. 1.2 (Kumar et al. 1993), while the cladograms (without the assumption of a molecular clock) were plotted using Treeview ver. 1.5.2 (Page 1998). The indices of gene flow (Fst and Nm) were calculated using DnaSP ver. 3 (Rozas \& Rozas 1999). Phylogenetic relationships among the nucleotide sequences were also inferred from a minimum spanning network with the use of MINSPNET (Exoffier \& Smouse 1994). Data were also analyzed with the split decomposition, using the parameter Parsimony Splits (Bandelt \& Dress 1993) in the SplitsTree program ver. 3.1 (Huson 1998). 
Table 1. Kimura 2-parameter distance (above the diagonal) and absolute value of K/SE (SE = standard error) (below the diagonal) among populations (1, West Australia; 2, South Australia; 3, Victoria; 4, Carteau; 5, Banyuls; 6, Alicante; 7, Taranto; 8, Çesme; 9, Naples; 10, Ischia; 11, Marseille; 12, Roscoff) of Sabella spallanzanii and outgroup Amphiglena mediterranea (13). OTUS: operational taxonomic units

\begin{tabular}{|lccccccccccccc|}
\hline OTUs & 1 & 2 & 3 & 4 & 5 & 6 & 7 & 8 & 9 & 10 & 11 & 12 & 13 \\
\hline 1 & & 0.0267 & 0.0044 & 0.0498 & 0.0452 & 0.0405 & 0.0545 & 0.0592 & 0.0405 & 0.0452 & 0.0405 & 0.0405 & 0.1711 \\
2 & 0.0110 & & 0.0222 & 0.0592 & 0.0452 & 0.0499 & 0.064 & 0.0688 & 0.0499 & 0.0546 & 0.0499 & 0.0499 & 0.1709 \\
3 & 0.0044 & 0.0100 & & 0.0451 & 0.0405 & 0.0359 & 0.0498 & 0.0545 & 0.0359 & 0.0405 & 0.0359 & 0.0359 & 0.1656 \\
4 & 0.0152 & 0.0167 & 0.0144 & & 0.0132 & 0.0088 & 0.0358 & 0.0358 & 0.0177 & 0.0222 & 0.0088 & 0.0497 & 0.1655 \\
5 & 0.0145 & 0.0145 & 0.0137 & 0.0076 & & 0.0044 & 0.0312 & 0.0312 & 0.0132 & 0.0177 & 0.0044 & 0.0451 & 0.1546 \\
6 & 0.0137 & 0.0152 & 0.0128 & 0.0062 & 0.0044 & & 0.0267 & 0.0267 & 0.0088 & 0.0132 & 0.0039 & 0.0404 & 0.1547 \\
7 & 0.0159 & 0.0174 & 0.0152 & 0.0127 & 0.0119 & 0.0109 & & 0.0267 & 0.0267 & 0.0312 & 0.0267 & 0.0591 & 0.1764 \\
8 & 0.0167 & 0.0181 & 0.0159 & 0.0127 & 0.0119 & 0.0109 & 0.0109 & & 0.0267 & 0.0312 & 0.0267 & 0.0497 & 0.1765 \\
9 & 0.0137 & 0.0152 & 0.0128 & 0.0089 & 0.0077 & 0.0062 & 0.0109 & 0.0109 & & 0.0044 & 0.0088 & 0.0404 & 0.1547 \\
10 & 0.0145 & 0.0160 & 0.0137 & 0.0100 & 0.0089 & 0.0077 & 0.0119 & 0.0119 & 0.0044 & & 0.0132 & 0.0451 & 0.1601 \\
11 & 0.0137 & 0.0152 & 0.0128 & 0.0062 & 0.0044 & 0.0028 & 0.0109 & 0.0109 & 0.0062 & 0.0077 & & 0.0404 & 0.1547 \\
12 & 0.0137 & 0.0152 & 0.0128 & 0.0151 & 0.0144 & 0.0136 & 0.0166 & 0.0151 & 0.0136 & 0.0144 & 0.0136 & & 0.1440 \\
13 & 0.0299 & 0.0299 & 0.0293 & 0.0293 & 0.0282 & 0.0282 & 0.0304 & 0.0305 & 0.0282 & 0.0288 & 0.0282 & 0.0270 & \\
\hline
\end{tabular}

\section{RESULTS}

\section{Nucleotide sequences and intraspecific divergence}

A total of $285 \mathrm{bp}$ of the nuclear ribosomal DNA (nrDNA) ITS2 nucleotide sequence from Sabella spallanzanii populations were aligned (EMBL accession no. AF205433). The number of informative sites was high, with an average of $96 \%$ similarity between sequences of the same population. The guaninecytosine (GC) content was the same for both S. spallanzanii and the outgroup Amphiglena mediterranea (sequence length of $236 \mathrm{bp}$ ), with an average of $34 \%$.

Most of the variation between populations of Sabella spallanzanii were nucleotide substitutions, except for a 6-base insertion (AGCCTC, position 68-74) in the Roscoff population and a 3-base insertion (GGA; positions 248-250) in all the Australian populations. Two repeated di-nucleotides were detected with low internal variability [(TC) 4 : 197-204; $(\mathrm{CT})_{3}$ : 279-283] between S. spallanzanii populations [(TC) $)_{5}: 197-206$ in the Roscoff population]. Kimura's (1980) 2-parameter distance (Table 1) was calculated both within and between the different geographical groups. Within the Australian group the ITS2 distance varied from 0.0044 to 0.0267 (mean $=0.017)$; within the Mediterranean group the distance ranged from 0.0039 to 0.0688 (mean $=0.033)$. Genetic divergence between the Australian and European populations ranged from 0.0039 to 0.0688 , with an average of 0.034 .

\section{Phylogenetic analyses}

Phylogenetic tree reconstruction methods such as distance (UPGMA) and maximum parsimony pro- duced similar trees for the ITS2 sequences of the Sabella spallanzanii populations (all the sequences were determined by consensus). Fig. 3a depicts the UPGMA tree, and Fig. 3b the maximum-parsimony tree; both include results from 1000 bootstrap replicates. Both algorithms of phylogeny reconstruction recovered the same topology, suggesting that the signal in the data is robust under different assumptions.

Two nodes were also significantly supported: the clade of Mediterranean populations, with a $95 \%$ bootstrap value in the consensus parsimony tree $(82 \%$ in genetic distance tree), and the clade of Australia populations, with a $96 \%$ bootstrap value.

Inside the Mediterranean group, where the lowest bootstrap values ( 40 and $54 \%$ ) occurred, the following division into 2 clades is evident: the group including the Taranto and Çesme populations (eastern Mediterranean) and the group involving the northwestern Mediterranean basin populations. In the latter group (60 and $42 \%$ ), it is also possible to distinguish 2 smaller clades: one with all the populations from the French and Spanish coasts and the other with the Ischia and Naples populations (central Mediterranean Basin).

Within the Australian populations, a certain degree of variability is evident; the populations from Victoria Bay and Cockburn Sound (Western Australia) cluster together and are separate from the South Australian population.

Although 3 sub-clades within the Mediterranean populations were identified and all the Australian populations are separated, the cladograms do not reveal clear biogeographical patterns for the Atlantic population. In the distance tree, the Roscoff population is more related to the Mediterranean ones (Fig. 3a), while in the most parsimony tree the Atlantic population is outside the other 2 population groups (Fig. $3 \mathrm{~b}$ ). 


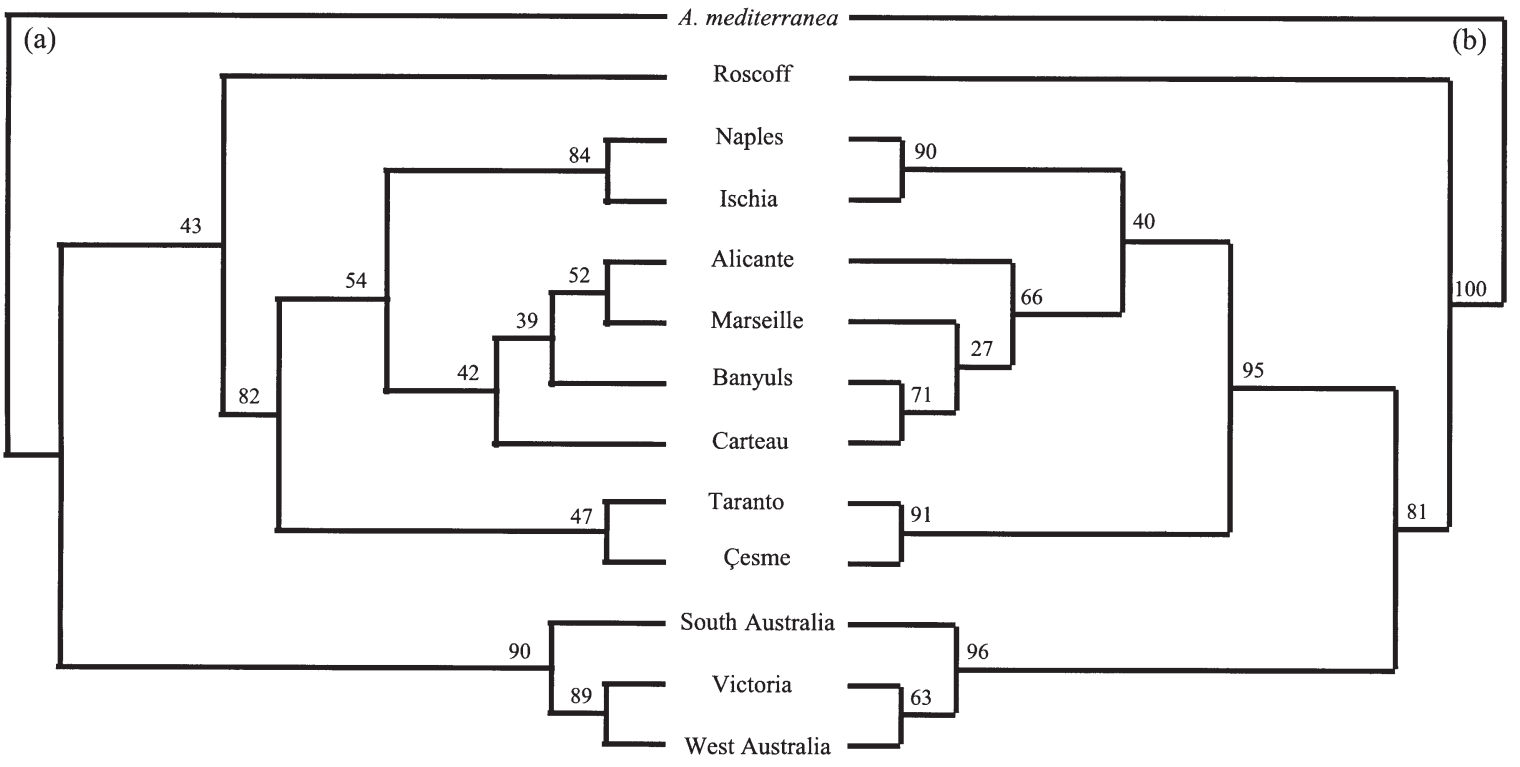

Fig. 3. Bootstrap consensus trees (1000 replicates) derived from (a) UPGMA and (b) maximum parsimony analysis based on the ITS2 sequences. Bootstrap values are displayed. See the text for a discussion of the model used

The unclear position of the Roscoff population (essentially due to the inadequate number of populations considered in the Atlantic) is depicted in the splittree reconstruction (Fig 4a). The split is indicated by the parallel bands (the 3 bold lines). Fig. 4a depicts distinctly the split of Roscoff versus the other Mediterranean populations, exhibiting again the contradictory relationship between the Atlantic population and all other ones.

For a better representation of the connections among populations of Sabella spallanzanii, an unrooted network was constructed considering all the sites (Fig. 4b). The network reveals a hierarchical relationship among populations and identifies 2 major geographical groups, based on nucleotide substitutions: the Australian populations and the Mediterranean

Table 2. Pairwise estimates of the rate of gene flow (absolute number of individuals exchanged between populations and generation, $\mathrm{Nm}$ ) (above diagonal) and $F_{\text {st }}$ (Wright's fixation index; below diagonal) (Hudson et al. 1992) among the 3 populations (Australian, Mediterranean, Atlantic) and within the 3 Mediterranean populations, using DnaSP (Rozas \& Rozas 1999)

\begin{tabular}{|lccc|}
\hline & Australian & Mediterranean & Atlantic \\
\hline Australian & - & 0.17 & 0.05 \\
Mediterranean & 0.595 & - & 0.08 \\
Atlantic & 0.838 & 0.767 & - \\
& Med-northwestern & Med-central & Med-oriental \\
& - & 0.17 & 0.38 \\
Med-northwestern & 0.600 & - & 0.22 \\
Med-central & 0.400 & 0.533 & - \\
Med-oriental & & & \\
\hline
\end{tabular}

populations. The Roscoff population (Atlantic) is also well separated, but the results are incongruous due to the insufficient number of populations considered.

The distribution of the Mediterranean populations suggests a subdivision at a smaller geographical scale, with at least 3 different sub-basins: northwestern (Alicante, Banyuls, Marseille and Carteau), central (Ischia and Naples) and eastern (Taranto and Çesme).

\section{DISCUSSION}

The study of the rDNA ITS2 spacer demonstrates that all the Sabella spallanzanii populations examined represent a unique species entity (Patti \& Gambi 1998) and has led to the discrimination of 2 well-separated groups of populations. The 2 cladograms, derived from genetic distances (UPGMA) and maximum-parsimony analysis, correspond well; the bootstrap values at the internodes are high and indicate the robustness of both trees. The nucleotide sequences of the ITS2 region reveal genetic differentiation among all the populations of $S$. spallanzanii, with $F_{\text {st }}$ (Wright's fixation index) ranging from 0.595 to 0.838 (Table 2) and from 0.533 to 0.600 among the Mediterranean populations. These data and the low rates of gene flow (absolute number of individuals exchanged between popula- 

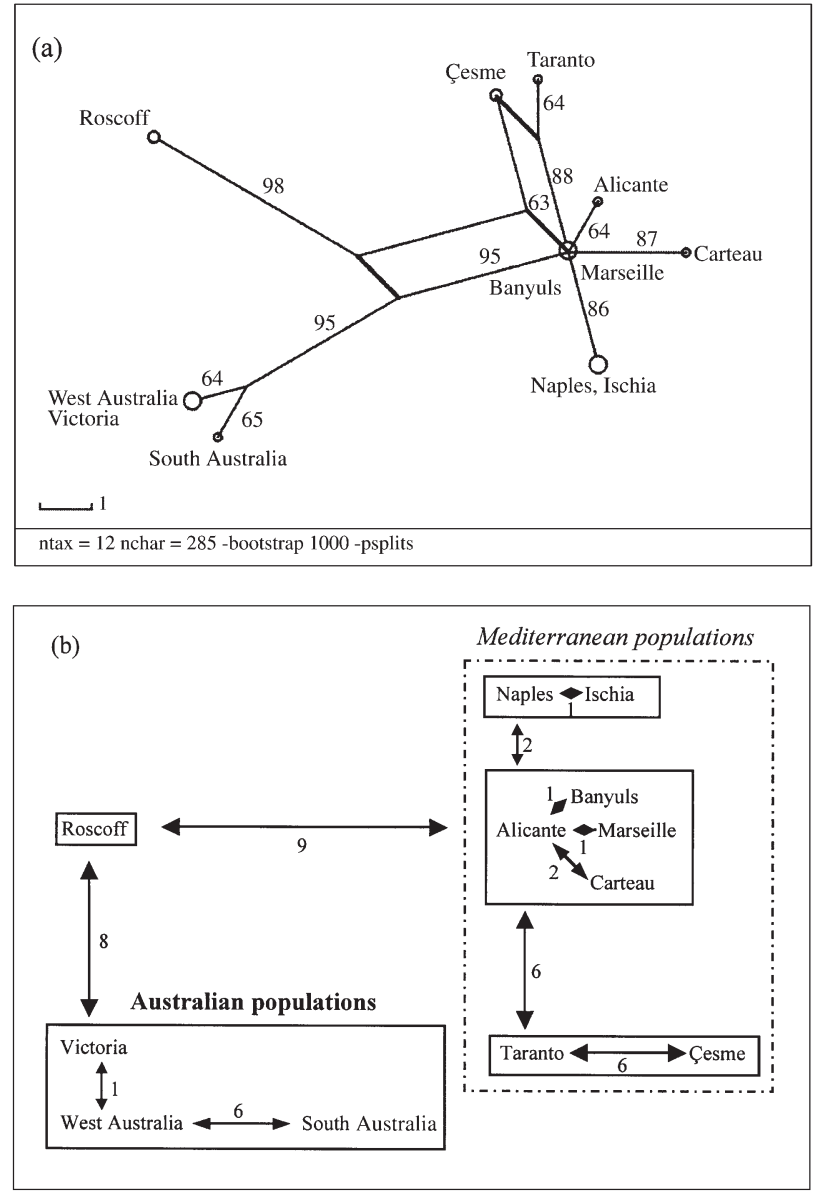

Fig. 4. (a) Split graph for the distances listed in Table 1 (numbers indicate the bootstrap value to test the statistical robustness of the computed split graph) and (b) the minimum spanning network generated using the method of Excoffier \& Smouse (1994) (numbers at nodes indicate the numbers of nucleotide changes between haplotypes)

tions and generation, $\mathrm{Nm}$, ranges from 0.17 to 0.38 ) in the Mediterranean populations suggest that gene dispersal is somewhat limited by physical constraints (Table 2).

Comparison of the molecular data with those obtained from allozyme analysis (Andrew \& Ward 1997) shows coherent results (Fig. 5); the Australian populations are gathered and disjoined from the European ones in both studies. This fact confirms a previous preliminary study (Patti \& Gambi 1998) and demonstrates that ITS2 is a good descriptor of the genetic structure of Sabella spallanzanii.

The variability in the composition and structure of the ITS2 in Sabella spallanzanii is consistent with the hypothesis of a high intrinsic genetic variability due to its ecological plasticity and to its high dispersal potential. The ecological value of the genus would explain the invasive capacities and the role of pest species assumed by this organism in Australian waters (Clapin \& Evans 1995). High variability in the structure of the ITS was also found in a group of green algae of the genus Caulerpa (Fama' et al. 2000), in particular in C. racemosa. This species, introduced in the Mediterranean Sea in the 1880s through the Suez Canal (Hamel 1926, 1931), is now reported within the eastern Mediterranean Basin (Verlaque et al. 2000). Following the existing information, it seems that ecological plasticity is often coupled with a high genetic variability; these characteristics could represent pre-requisite features for successful colonization of an allocthonous species in a new geographic area or habitat (Olsen et al. 1998).

(a)

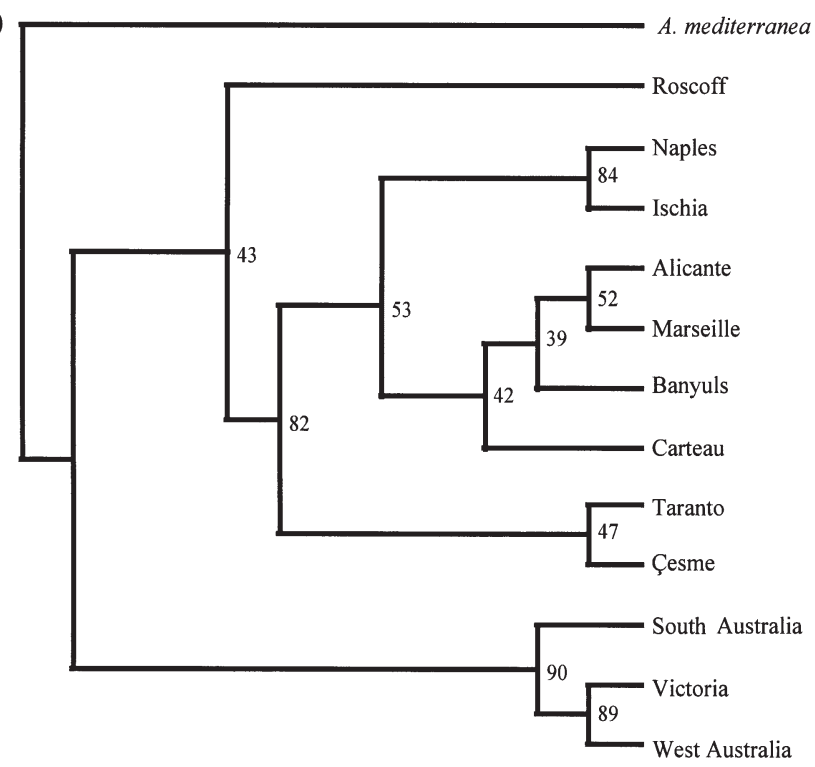

(b)
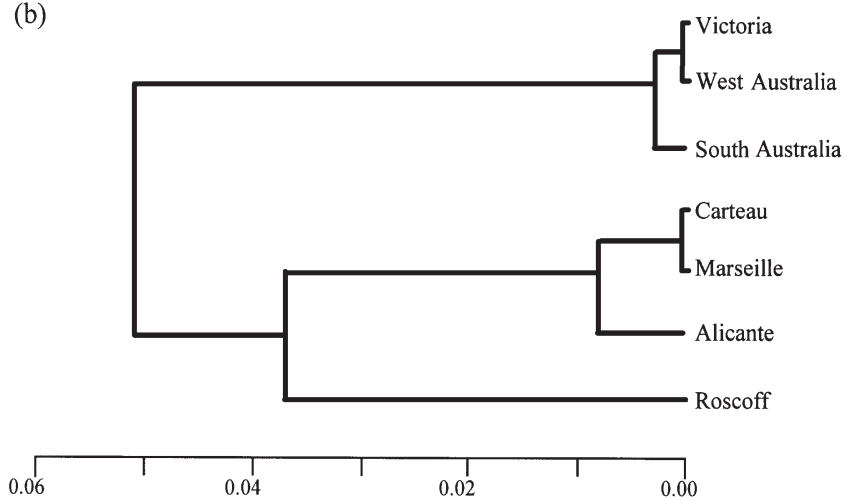

Fig. 5. Genetic relationship among Sabella spallanzanii populations, derived (a) from the genetic distance (UPGMA) obtained in the present analysis and (b) from a matrix of Nei's (1978) unbiased genetic distance with isozyme data (modified from Andrew \& Ward 1997) 
Moreover, when the ITS2 regions are very short and under strong evolutionary pressure, the DNA sequence can be highly conserved in order to maintain the RNA secondary structure involved in the post-transcriptional processing of rRNA (Mari et al. 1999). In any case more data on the genetics of introduced and invasive species are necessary.

The separation of the 3 Australian populations into 2 different clades and the geographical discontinuity between them suggests 2 separate invasions at 2 separate times into Western and Southern Australia and to Southeastern Australia, as indicated by the chronology of the records of Sabella spallanzanii (Fig. 1). The introduction of $S$. spallanzanii along the Australian coasts might have happened through carriage of larvae or juveniles in ballast water. The other hypothesis that cannot be excluded is an introduction through the communities fouling ships' hulls. Nevertheless, S. spallanzanii is not typically found to foul hulls. Besides, populations of $S$. spallanzanii are not described along the Atlantic coast of Africa or in other areas between Europe and Australia. Moreover, at present relatively few organisms appear to arrive through the fouling of ships' hulls compared to the past. This decrease is due to the use of anti-fouling paints as well as fast ship speeds. In addition, the animals may not be capable of bearing the thermal gradient from the moderate-towarm waters of the Mediterranean to warm equatorial waters to cold sub-Antarctic waters.

Within the Australian waters, Sabella spallanzanii has not been observed along the northern coast. One of the most probable hypotheses is that the different types of circulation of the warm equatorial and cold circumpolar tides are a strong climatic barrier to the dispersion of this species. S. spallanzanii, in fact, is a warm-temperate species that optimally colonises locations in the Mediterranean climate. The identification of the vector of the invasion toward Australian waters is also important for genetic implications. An introduction through larvae implicates the introduction of the genetic pool from a limited area and therefore the individuals will be genetically more homogeneous. Introduction through fouling can spread out the genetic pool so that there is greater genetic variability, individuals deriving from distinct areas and different populations.

The fate of the larvae and the study of the first phases of metamorphosis to the adult stage represent crucial information in better understanding the dynamics of the Sabella spallanzanii invasion into Australian waters and the population distribution in the Mediterranean Basin. Larval development in S. spallanzanii has recently been described under laboratory conditions by Giangrande et al. (2000). The fertilized eggs, in mucous egg masses, sink to the bottom of a petri dish. After hatching, the swimming lecithotrophic larvae are characterized by 3 segments and have a relatively long pelagic life-up to $15 \mathrm{~d}$, the longest among Sabellidae (Giangrande 1997, Giangrande et al. 2000). Settlement of larvae, in the stage with 3 segments, was observed when a suitable substrate (shell debris) was placed in the petri dish, suggesting that larvae may have the potential plasticity to modify the length of the pelagic phase (Giangrande et al. 2000). The larvae start metamorphosis $10 \mathrm{~d}$ after settlement, developing the branchial crown and the mucous tube (Giangrande et al. 2000). These observations confirm that the species has a high dispersal capacity, and that the larvae could survive for a long period in ballast water, in both the pelagic and post-settlement phases (approx. $25 \mathrm{~d}$ ). However, this high dispersal capacity may contrast with the genetic differentiation between sub-basins, observed within the Mediterranean Sea. Although long-living larval stages confer a great dispersal potential in general (Shuto 1974, Jablonski \& Lutz 1983, Palumbi 1995, Pechenik 1999), large- or medium-scale hydrodynamic processes may strongly influence the larval transport and therefore could constitute potential barriers to dispersion and gene flow among populations. The pattern of water circulation within the different basins of the Mediterranean Sea (Tait 1984, Robinson et al. 1992, Malanotte-Rizzoli et al. 1999) could limit larval transport and favor genetic differentiation among the Mediterranean populations. At a smaller spatial scale, within the Tyrrhenian Sea, a similar phylogeographic pattern has been demonstrated for the endemic seagrass Posidonia oceanica (Procaccini \& Mazzella 1998, Procaccini et al. 2000), which possesses a sexual dispersion mechanism, via floating fruits, that can be compared to that of an invertebrate larval stage. Moreover, some of the populations of S. spallanzanii occurring in harbors or other polluted areas are relatively short lived and often show high mortality (Giangrande pers. comm.); this mechanism can favor differentiation due to the increasing genetic drift of the relatively few surviving specimens.

The possible geographical origin of the Australian invasive populations is arduous to formulate. Andrew \& Ward (1997) hypothesized the origin of the invasion to be the Mediterranean, with a loss in the Australian populations of around $18 \%$ of the original genetic variability, due to the 'founder effect' of the first introduced population. ITS2 sequences are not sufficient to clarify the origin of the Australian populations because of the intermediate position of the Roscoff population; the latter could be better identified with the analysis of other Atlantic populations. However an introduction to Australia from Europe has evidently caused a loss of genetic polymorphism, probably because of a single input in the colonization of the new environment. This 
population has then spread out, diversifying in the bordering areas, but preserving the genetic stability of the first installation. The sequence similarity found between the Mediterranean populations and the Australian populations supports the hypothesis that only 1 population of Sabella spallanzanii is responsible for the Australian water colonization. The observation of reduced genetic variability due to the founder effect seems to be more consistent with the possibility of introduction through ballast water, and therefore only 1 larval pool for the different Australian populations.

Acknowledgements. We wish to thank Dr R. Ward (CSIRO, Australia) for providing material for the analysis of Australian, Roscoff and some of the Mediterranean populations. We are also grateful to Dr E. Cinar and Dr A. Giangrande for providing specimens from Turkey and Taranto respectively and to Dr J. P. Feral for contribution to an early analysis of ITS2 sequences.

\section{LITERATURE CITED}

Andrew J, Ward RD (1997) Allozyme variation in the marine fanworm Sabella spallanzanii: comparison of native European and introduced Australian populations. Mar Ecol Prog Ser 152:131-143

Bandelt HJ, Dress AWM (1993) A relational approach to split decomposition. In: Opitz O, Lausen B, Klar R (eds) Information and classification. Springer, Berlin, p 123-131

Bitar G (1987) Étude des peuplements benthiques littoraux des côtes atlantiques et mediterranéennes du Maroc. Impact de la pollution, comparaisons biogéographiques. These, Univ D'Aix-Marseille 2

Carey JM, Watson JE (1992) Benthos of the muddy bottom habitat of the Geelong Arm of Port Phillip Bay, Victoria, Australia. Vic Nat 109(6):196-202

Carlton JT (1996) Biological invasions and cryptogenic species. Ecology 77:1653-1655

Clapin G, Evans D (1995) The status of the introduced marine fan worm Sabella spallanzanii in Western Australia: a preliminary investigation. July 1995. CSIRO Division of Fisheries Marine Life Fact Sheet

Currie DR, McArthur MA, Cohen BF (2000) Reproduction and distribution of the invasive European fan worm Sabella spallanzanii (Gmelin) (Polychaeta: Sabellidae) in Port Phillip Bay, Victoria, Australia. Mar Biol 136:645-656

Doyle JJ, Doyle JJ (1987) A rapid DNA isolation procedure for small quantities of fresh leaf tissue. Phytochem Bull 19:11-15

Exoffier L, Smouse PE (1994) Using allele frequencies and geographic subdivision to reconstruct gene trees within a species: molecular variance parsimony. Genetics 136: 343-359

Fama' P, Olsen JL, Stam WT, Procaccini G (2000) High levels of intra- and inter-individual polymorphism in the rDNA ITS1 of Caulerpa racemosa (Chlorophyta). Eur J Phycol 35(4):349-356

Felsenstein J (1994) PHYLIP (Phylogeny Inference Package) version 3.5.6c. Distributed by the author. Department of Genetics, University of Washington, Seattle

Giangrande A (1997) Polychaete reproductive patterns, life cycles and life histories: an overview. Oceanogr Mar Biol Annu Rev 35:323-386
Giangrande A, Gambi MC (1998) Anellidi Policheti come nuova risorsa marina: un esempio con alcuni Sabellidi. Biol Ital 10:13-19

Giangrande A, Petraroli A (1994) Observation on reproduction and growth of Sabella spallanzanii (Polychaeta, Sabellidae) in the Mediterranean Sea. In: Dauvin JC, Laubier L, Reish DJ (eds) Actes de la 4ème Conference internationale des Polychètes. Mem Mus Natl Hist Nat Paris 162:51-56

Giangrande A, Licciano M, Pagliara P, Gambi MC (2000) Gametogenesis and larval development in Sabella spallanzanii (Polychaeta: Sabellidae) from the Mediterranean Sea. Mar Biol 136:847-862

Hallegraeff GM, Bolch CJ (1991) Transport of toxic dinoflagellate cysts via ships ballast water. Mar Pollut Bull 22: $27-30$

Hallegraeff GM, Steffensen DA, Wetherbee R (1998) Three estuarine Australian dinoflagellates that can produce paralytic shellfish toxin. J Plankton Res 10:533-541

Hamel H (1926) Quelques algues rares ou nouvelles pour la flore méditerranéenne. Bull Mus Natl Hist Nat Paris 32: 420

Hamel H (1931) Origine de la flore de la Méditerranée orientale. Travaux cryptogamiques dédiés à L. Mangin, Paris

Hudson RR, Boos DD, Kaplan NL (1992) A statistical test for detecting population subdivision. Mol Biol Evol 9:138-151

Huson DH (1998) SplitsTree: a program for analyzing and visualizing evolutionary data. Bioinformatics 14(1):68-73

Jablonski D, Lutz R (1983) Larval ecology of marine benthic invertebrates: paleobiological implications. Biol Rev 58: 21-89

Jamieson BGM, Rouse G (1989) The spermatozoa of Polychaeta (Annelida): an ultrastructural review. Biol Rev 64: 93-157

Kimura M (1980) A simple method for estimating evolutionary rate of base substitutions through comparative studies of nucleotide sequences. J Mol Evol 16:111-120

Knight-Jones P, Perkins TH (1998) A revision of Sabella, Bispira and Stylomma (Polychaeta: Sabellidae). Zool J Linn Soc 123:385-467

Kumar S, Tamura K, Nei M (1993) MEGA: Molecular Evolutionary Genetics Analysis, version 1.2. The Pennsylvania State University, University Park

Malanotte-Rizzoli P, Manca BB, Ribera d'Alcalà M, Theocharis A, Brenner S, Bulillon G, Ozsoy E (1999) The Eastern Mediterranean in the 80s and in the 90s: the big transition in the intermediate and deep circulations. Dyn Atmos Oceans 29:365-395

Mari LS, LoBuglio KF, Rogers SO (1999) Comparison of ribosomal DNA ITS regions among geographic isolates of Cenococcum geophilum. Curr Genet 35:527-535

Nei M (1978) Estimation of average heterozygosity and genetic distance from a small number of individuals. Genetics 89:583-590

Nicholas KB, Nicholas HB Jr, Deerfield DW II (1997) GenDoc: analysis and visualization of genetic variation. EMBNEW. NEWS 4:14

Office of Technology Assessment (US Congress) (1993) Harmful non-indigenous species in the United States. OTA Publication OTA-F-565, US Government Printing Office, Washington, DC

Olsen JL, Valero M, Meusnier I, Boele-Bos S, Stam WT (1998) Mediterranean Caulerpa taxifolia and C. mexicana (Chlorophyta) are not conspecific. J Phycol 34:850-856

Page RDM (1998) TREEVIEW: an application to display phylogenetic trees on personal computers. Comput Appl Biosci 12:357-358 
Palumbi SR (1995) Using genetics as an indirect estimator of larval dispersal. In: McEdward L (ed) Ecology of marine invertebrate larvae. CRC Press, Boca Raton, FL, p 369-387

Patti FP, Gambi MC (1998) Relationships between different populations of Sabella spallanzanii (Gmelin) (Polychaeta, Sabellidae): comparison of genetic descriptors and techniques. Boll Mus Civ St Nat Verona (2nd Ser) (sez Scienze della vita) 13:53-56

Pechenik JA (1999) On the advantages and disavantages of larval stages in benthic marine invertebrate life cycles. Mar Ecol Prog Ser 177:269-297

Procaccini G, Mazzella L (1998) Population genetic structure and gene flow in the seagrass Posidonia oceanica assessed using microsatellite analysis. Mar Ecol Prog Ser 169: 133-141

Procaccini G, Orsini L, Ruggiero MV (2000) Genetic structure and distribution of microsatellite diversity in Posidonia oceanica. In: Pergent G, Pergent-Martini C, Buia MC, Gambi MC (eds) Proceedings 4th Seagrass Biology Workshop (Corsica, 26 September-2 October 2000). Biol Mar Medit 7(2):115-118

Robinson A, Malanotte-Rizzoli P, Hecht A, Michelato A, Roether W, Teocharis A, Unluata U, Pinardi N, Artegiani A, Bergmasco A, Brenner S, Gaèiæ M (1992) General circulation of the Eastern Mediterranean. Earth Sci Rev 32:285-309

Rozas J, Rozas R (1999) DnaSP version 3: an integrated program for molecular population genetics and molecular evolution analysis. Bioinformatics Appl Note 15(2): 174-175

Ruiz GM, Carlton JT, Grosholz ED, Hines AH (1997) Global

Editorial responsibility: Otto Kinne (Editor),

Oldendorf/Luhe, Germany invasions of marine and estuarine habitats by non-indigenous species: mechanisms, extent, and consequences. Am Zool 37:621-632

Sambrook J, Fritsch EF, Maniatis T (1989) Molecular cloning, 2nd edn. Cold Spring Harbor Lab Press, Cold Spring Harbor, NY

Shuto T (1974) Larval ecology of prosobranch gastropods and its bearing on biogeography and paleontology. Lethaia 7 : 239-256

Swofford DL (2000) Paup*. Phylogenetic Analysis Using Parsimony ( ${ }^{*}$ and other methods), Version 4.0. Sinauer Associates, Sunderland, MA

Tait RT (1984) The physical oceanography of the Tyrrhenian and Ligurian Seas. In: Cinelli F, Fabiano M (eds) Proceedings VI Congress of the Associazione Italiana di Oceanologia e Limnologia (A.I.O.L.). AIOL, Livorno, p 49-84

Thompson JD, Gibson TJ (1998) ClustalX version 1.64b. Distributed by the authors. European Molecular Biology Laboratory, Heidelberg

Thompson JD, Higgins DG, Gibson TJ (1994) ClustalW: improving the sensitivity of progressive multiple sequence alignment through sequence weighting, position specific gap penalites and weight matrix choice. Nucleic Acids Res 22:4673-4680

Verlaque M, Boudouresque CF, Meinesz A, Gravez V (2000) The Caulerpa racemosa complex (Caulerpales, Ulvophyceae) in the Mediterranean Sea. Bot Mar 43:49-68

White TJ, Bruns T, Lee S, Taylor J (1990) Amplification and direct sequencing of fungal ribosomal RNA genes for phylogenetics. In: Innis MA, Gelfand DH, Sninsky JJ, White TJ (eds) PCR protocols: guide to methods and applications. Academic Press, San Diego, p 315-322

Submitted: September 11, 2000; Accepted: February 6, 2001 Proofs received from author(s): May 14, 2001 